the 'half-distance' of image spread) of no greater than 35 per cent.

J.R.J. BAKER Ciba-Geigy Pharmaceuticals, Horsham, West Sussex RH12 4AB, UK

M.A. Williams Department of Anatomy and Cell Biology, University of Sheffield, Sheffield, UK

SIR-Contrary to what Hall et al. ${ }^{\prime}$ imply, quantitative autoradiography was developed and used to measure local rates of cerebral blood flow by Kety and coworkers $^{2-4}$ well before 1981. This technique has also been applied to determination of local rates of biochemical processes in vivo ${ }^{5,6}$. Quantitative autoradiography, like all techniques, has some pitfalls ${ }^{7}$, but some of the potential errors described by Hall et al. are products of their own confusion. Standardization of optical density values against radioactive plastic standards is an accepted method with few problems if it is understood and carried out correctly. Calibration against homogeneously labelled brain tissue sections cut at the prescribed thickness is simple and straightforward. The units to be used are determined by this procedure. They are either d.p.m. or $\mu \mathrm{Ci}$ per gram wet weight of tissue. It would be possible to convert values to d.p.m. or $\mu \mathrm{Ci}$ per $\mathrm{mg}$ tissue protein if concentrations of protein in particular brain regions were known but the reason for the choice of d.p.m. per $\mathrm{mm}^{2}$ by Hall et al. is not clear.

With regard to the problem of relatively short-lived isotopes, an alternative procedure could be devised. Brain sections labelled with the short-lived isotope, such as ${ }^{131} \mathrm{I}$, could be cross-calibrated against ${ }^{14} \mathrm{C}$-labelled methylmethacrylate standards. With this approach it is possible to correct for decay mathematically and use a set of standards over and over again.

Consiglio Nationale delle Ricerche,

Centro Studie Fisiologia Del Lavoro

Muscolare,

I-20132, Italy

Laboratory of Cerebral Metabolism,

C.B. SMITH

National Institute of Mental Health,

Bethesda, Maryland 20892, USA

1. Hall, M.D., Davenport, A.P. \& Clark, C.R. Nature 324 493-494 (1986).

2. Landau, W.M., Freygang, W.H., Rowland, L.P., Sokoloff, L. \& Kety, S.S. Trans. Am. neurol. Ass. 80, 125-129 (1955).

3. Freygang, W.H. \& Sokoloff, L. Adv. biol. med. Phys. 6 263-279 (1958).

4. Reivich, M., Jehle, J., Sokoloff, L. \& Kety, S.S. J. appl. Physiol. 27, 296-300 (1969)

5. Sokoloff, L. et al. J. Neurochem. 28, 897-916(1977)

6. Smith, C.B., Crane, A.M., Kadekaro, M., Agranoff, B.W. \& Sokoloff, Crane, A.M., Kadekaro, M., Agra

7. Sokoloff, L., Kennedy, C. \& Smith, C.B. in Research Methods in Neurochemistry Vol. 6 (eds Marks, N. \& Rodnight, R.) 79-116 (Plenum, New York, 1985)

HALL AND DAVENPORT REPLY-Baker and Williams are, of course, right to point out that ${ }^{125} \mathrm{I}$ emits electrons and not $\beta$ - particles as our original text said*. But, according to Rogers ${ }^{1}$, and contrary to the statement of Baker and Williams, electrons derived from ${ }^{125} \mathrm{I}$ have a range of energies, the most abundant of which are: $2.8 \mathrm{keV}(27.7 \%), 3.6 \mathrm{keV}(48.8 \%), 22.5$ $\operatorname{keV}(14.2 \%), 31.0 \mathrm{keV}(6.7 \%)$ and 34.3 $\operatorname{keV}(1.2 \%)$. In micro- and macroradiography, the relative contribution of these electrons to the blackening of the emulsion is not clear. We can say, however, that under experimental conditions selfabsorption of electrons derived from ${ }^{125} \mathrm{I}$ is much less than that of $\beta$-emissions from ${ }^{3} \mathrm{H}$. In addition, it is generally understood that $\mathrm{X}$ rays and $\gamma$ rays contribute little to the production of an image ${ }^{1}$. A ${ }^{125}$ I polymer-based standard is indeed now commercially available.

With regard to our statement on crystal diameter of the emulsion, Ultrofilm has a reported average diameter of $1.8 \pm$ $0.3 \mu \mathrm{m}$, whereas Ilford $\mathrm{K} 5$ emulsion, used in the coverslip technique, is reported to be $0.2 \mu \mathrm{m}$. This second method affords greater anatomical resolution ${ }^{1}$. If a commercial supplier could coat a polymerbased film with, for example, K5 emulsion, the anatomical resolution would be enhanced; we consider $35 \%$ a significant improvement for our application.

In response to Lucignani and Smith, our article was confined to a discussion on receptor autoradiography for brevity, although we were familiar with the use of quantitative autoradiography in related techniques, such as measurement of cerebral blood flow and glucose utilization.

Our reasons for using d.p.m. per $\mathrm{mm}^{2}$ are quite clear. Three absolute measurements can be made from standard sections, namely optical density, surface area and radioactivity. Using this method it is not necessary to make any assumptions or confuse standard tissue weight per protein with sample protein. We agree that protein measurement within individual brain regions is the ideal situation and a method for performing this has been described ${ }^{2}$.

It is naive to assume that images produced by ${ }^{14} \mathrm{C}$ ( $\beta$-emission maximum 158 $\mathrm{keV}$; mean $50 \mathrm{keV}$ ) can be compared to images produced by ${ }^{131} \mathrm{I}$, which emits $\beta$ particles with energy ranges $(250 \mathrm{keV}$, $3 \% ; 330 \mathrm{keV}, 9 \% ; 610 \mathrm{keV}, 87 \% ; 810$ $\mathrm{keV}, 1 \%)^{1}$.

M.D. HALL

Parke Davis Research Unit,

A.P. DAVENPORT

Addenbrookes Hospital Site,

Hills Road, Cambridge, CB2 2QB, UK

1. Rogers, A.W. Techniques of Autoradiography 3rd edn (Elsevier, Amsterdam, 1979)

2. Chicz-DeMet, A. et al. Soc. Neurosci. Abst. 12, 144 (1986).

"Erratum. Because of errors introduced in the editorial process, the following corrections should be made to the article by M.D. Hall, A.P. Davenport and C. R. Clark (Nature 324, 493494; 1986): para. 1 , line 9 -replace ref. 1 by $1-3$; para. 5 , line 4 -replace quantitative by qualitative; para. 6, line 19-replace $\beta$-particles by electrons; references - include 5, Clark, C.R. \& Hall, M.D. Trends biochem. Sci.11, 195-199 (1986).

\section{The representation of data in graphs and tables}

SIR-Now that Beedle ${ }^{1}$ has finally resolved the long-running controversy on the presentation of data in graphs and tables, it is worth going back to understand the origin of the problem.

Each unit used for a physical quantity allows an unequivocal identification of the quantity itself: for example, if the unit is the metre, we are sure that the quantity is a length. If this is good, on the other hand it has revealed a dangerous pitfall as far as our problem goes. On an axis, it is clearly necessary to indicate both the name of the physical quantity and the unit of measure (or multiples or submultiples of either or both). Thus, it is permissible to use

$\frac{\text { length }}{\text { (metres) }}, \frac{\text { length } \times 10^{-3}}{(\text { metres })}$ or $\frac{\text { length }}{\left(\text { metres } \times 10^{-3}\right)}$

but it is not acceptable to use

$$
\overline{\left(\text { metres } \times 10^{-3}\right)}
$$

to mean one thousandth of the length because this mistakes the unit for the denomination of the quantity.

In fact, if the unit could indicate more than one quantity, we are forced to label the quantity clearly. Thus,

$$
\frac{\text { length }}{\left(\text { metres } \times 10^{-3}\right)}
$$

would clearly say that the physical quantity is measured in millimetres. This is the exact opposite of what Luykx ${ }^{2}$ and those who agree with him would indicate. Nobody can prevent them from writing 'c.p.m. $\times 10^{-3}$ ' meaning that these are 'one thousandth of the registered c.p.ms'. Nevertheless, if we intend to be scientific, let us use the most explicit and simple method of labelling.

Istituto di Farmacologia,

MORENO PAOLINI

Università degli Studi,

Via Irnerio 48 ,

40126 Bologna, Italy

Giovanni Cercignani Carlo Bauer

Dipartimento di Fisiologia e Biochimica,

Università degli Studi,

Via S. Maria 55, 56100 Pisa, Italy

1. Beedle, A. S. Nature 325,305 (1987).

2. Luykx, P. Nature 315, 462 (1985).

\section{Scientific Correspondence}

Scientific Correspondence is intended to provide a forum in which readers may raise points of a scientific character. They need not arise out of anything published in Nature. In any case, priority will be given to letters of less than 500 words and five references. 